\title{
SUSTAINABLE DEVELOPMENT OF TERRITORIES
}

\author{
Luminiţa FILIMON \\ University of Oradea, Oradea, Faculty of Geography, Tourism and Sport, ROMANIA \\ palelumi@yahoo.com
}

\section{Corina TĂTAR}

University of Oradea, Oradea, Faculty of Geography, Tourism and Sport, ROMANIA corina_criste_78@yahoo.com

The collective volume entitled "Développement durable des territoires" brings together, under the coordination of Professors Jean-Paul Carrière, Abdelillah Hamdouch and Corneliu laţu, the papers presented in the French section "Innovation et développement territorial durable" of the $36^{\text {th }}$ edition (2016) of the "Dimitrie Cantemir" International Geographical Seminar, a tradition

sous la direction de

Jean-Paul Carrière

Abdelillah Hamdouch

Corneliu Iaţu

Développement durable des territoires

O ECONOMICA Anthropos within the geographical citadel of laşi.

The purpose of the paper is clearly expressed by the coordinators in the introduction: "the book aims to advance the reflection on the answers to be given, in terms of DTD, on the territorial changes observed at the beginning of the 21st centrury, in particular those resulting from the ongoing restructuring of the developing international territories" (Carrière et al., 2016, p. 14).

Including 14 chapters grouped in three distinct parts, written by researchers from different scientific fields, the book brings to specialists' attention the complex and up-to-date issues of the articulation between territorial development and sustainable development, explored both theoretically, conceptually and methodologically, as well as operational applicative, by the way it is transposed into the practice of territorial development, in different states and at different scales (national, regional, local), from different perspectives (academic, institutional) and through different mechanisms (classical, 
innovative): "all in all, this conceptual hybridization that we propose must allow progress to be made in the construction of 'project territories' where sustainability and new governance can be combined, involving all development actors" (Carrière et al., 2016, p. 16).

The first part of the book brings together five chapters devoted to the way that the application of sustainable development at different territorial scales declined, from the metropolis of Paris to the small cities or rural areas, revealing both the gaps between the conceptual evolution and territorial practices, as well as the perspectives of territorial development as an innovative way for local communities.

The second part contains five chapters that focus on the territorial organization and governance debate as tools for the application of sustainable territorial development in various states (Canada, Algeria, and Romania), the case of Romania being presented by two chapters dedicated to the regionalization process, namely local factors with a potential leveraging role in the sustainable territorial development.

The third part relates to the articulation between landscape, tourism and sustainable development, analysing tourism as a vector of sustainable local development. The leveraging role of landscape for the local sustainable development is argued at the scale of small and medium-sized towns for which landscape can become a strategic spatial planning tool or at the scale of a particular area, i.e. the Subcarpathians of Wallachia, for which the sustainable tourist development project must be integrated into the building of territorial capacities. The issue is further on carried out in the Romanian context, the construction of local governance as a premise for tourism transformation into a lever of sustainable territorial development. Starting from concrete results obtained from surveys carried out in mountain resorts of France, the need for innovation to open up sustainable tourism prospects supporting sustainable local development is highlighted.

The book is particularly interesting from the point of view of integrating the articulation of the two concepts into the contemporary landmarks of metropolisation and globalization that disrupt territorial hierarchies and raise interesting thoughts on space justice. Equally remarkable is the reflexive analysis on the sustainable development territorialisation as a challenge in the context of globalization and of the "crisis of territories" (Bailly, p. 10) and leads the debate on the resilient management of the territory (Carrière et al., p. 26), which is related to sustainable territorial development, irrespective of the territorial scale, governance, and the public action tools. The reflexive analysis continues with the conclusions of the paper that underline the essential conditions for the elaboration of a resilient territorial project: the identification of the active and latent resilience points, the elaboration of a strategic territorial diagnosis that includes all the dimensions of the sustainable territorial development and the rethinking of the governance and of the local public perimeters from the functional perspective (Carrière et al., pp. 226-227).

Therefore, from a perspective of maximum complexity and scientific validity, this work confirms the topicality of the debate on sustainable territorial development that has livened up the academic circles for approximately two decades and continues to pose a challenge for practitioners in this field, which recommends it not only to academia, but also to decision-makers. 


\section{REFERENCES}

BAILlY, A. (2016). Prèface. In Carriere J.-P., Hamdouch A., lațu C. (eds.), Développement durable des territoires (pp. 9-11). Paris: Economica-Anthropos.

CARRIERE, J.-P., HAMDOUCH, A., \& IAȚU, C. (eds.) (2016). Développement durable des territoires. Paris: Economica-Anthropos.

CARRIERE, J.-P., HAMDOUCH, A., \& IAȚU, C. (2016). Introduction. In Carriere J.-P., Hamdouch A., lațu C. (eds.), Développement durable des territoires (pp. 13-27). Paris: Economica-Anthropos.

CARRIERE, J.-P., HAMDOUCH, A., \& IAȚU, C. (2016). Conclusion. In Carriere J.-P., Hamdouch A., lațu C. (eds.), Développement durable des territoires (pp. 221-228). Paris: Economica-Anthropos. 